\title{
Thalidomide with blockade of co- stimulatory molecules prolongs the survival of alloantigen-primed mice with cardiac allografts
}

\author{
Maoshu Zhu ${ }^{1,2+}$, Yunhan Ma ${ }^{3,4+}$, Kai Tan ${ }^{5}$, Liyi Zhang ${ }^{3,4}$, Zhaowei Wang ${ }^{1,2}$, Yongsheng Li1 ${ }^{1,2}$, Yingyu Chen ${ }^{3,4}$, \\ Junjun Guo ${ }^{3,4}$, Guoliang Yan ${ }^{3,4^{*}}$ and Zhongquan $\mathrm{Qi}^{3,4,6^{*}}$
}

\begin{abstract}
Background: Miscellaneous memory cell populations that exist before organ transplantation are crucial barriers to transplantation. In the present study, we used a skin-primed heart transplantation model in mouse to evaluate the abilities of Thalidomide (TD), alone or in combination with co-stimulatory blockade, using monoclonal antibodies (mAbs) against memory T cells and alloantibodies to prolong the second cardiac survival.

Results: In the skin-primed heart transplantation model, TD combined with mAbs significantly prolonged the second cardiac survival, accompanied by inhibition of memory $\mathrm{CD}^{+} \mathrm{T}$ cells. This combined treatment enhanced the $\mathrm{CD}^{+}{ }^{+} \mathrm{Foxp}^{+}{ }^{+}$regulatory $\mathrm{T}$ cells ratio in the spleen, restrained the infiltration of lymphocytes into the allograft, and suppressed the allo-response of spleen T cells in the recipient. The levels of allo-antibodies also decreased in the recipient serum. In addition, we detected low levels of the constitutions of the lytic machinery of cytotoxic cells, which cause allograft damage.
\end{abstract}

Conclusions: Our study indicated a potential synergistic action of TD in combination with with mAbs to suppress the function of memory $T$ cells and increase the survival of second allografts in alloantigen-primed mice.

Keywords: Thalidomide, Co-stimulatory molecule, Monoclonal antibody, Cardiac allograft, Alloantigen, Memory T cell

\section{Background}

Memory $\mathrm{T}$ cells (Tms) are important immune system cells that protect against pathogen invasion. In adults, memory phenotypes are exhibited by $40-50 \%$ of $\mathrm{T}$ cells circulating in the peripheral blood [1]. Alloreactive Tms can be developed by transplantation recipients if they were exposed to the alloantigen during previous

\footnotetext{
* Correspondence: zhuanyiyan@126.com; zqqi@xmu.edu.cn

${ }^{+}$Maoshu Zhu and Yunhan Ma contributed equally to this work and should share the first authorship

${ }^{3}$ Organ Transplantation institute, School of Medicine, Xiamen University, Xiamen 361100, Fujian, China

Full list of author information is available at the end of the article
}

transplantations, blood transfusions, and pregnancies, or as a result of the continuous exposure to viral pathogens and bacteria. These memory cells play a pivotal role in poor allograft outcomes [2-4]. Compared with naïve cells, Tms have lower activation thresholds, precommitted cytokine profiles, and fewer dependent costimulations $[5,6]$, which make them significant obstacle to prolonging allograft survival after initial and secondary transplants. $\mathrm{CD} 4^{+} \mathrm{Tms}$ and $\mathrm{CD} 8^{+} \mathrm{Tms}$ are two important components of Tms. Primed $\mathrm{CD}^{+} \mathrm{Tms}$ can continuously infiltrate the allograft within $72 \mathrm{~h}$ posttransplantation, and $\mathrm{CD}^{+}$Tms-produced interferon

(c) The Author(s). 2020, corrected publication 2022. Open Access This article is licensed under a Creative Commons Attribution 4.0 International License, which permits use, sharing, adaptation, distribution and reproduction in any medium or format, as long as you give appropriate credit to the original author(s) and the source, provide a link to the Creative Commons licence, and indicate if changes were made. The images or other third party material in this article are included in the article's Creative Commons licence, unless indicated otherwise in a credit line to the material. If material is not included in the article's Creative Commons licence and your intended use is not permitted by statutory regulation or exceeds the permitted use, you will need to obtain permission directly from the copyright holder. To view a copy of this licence, visit http://creativecommons.org/licenses/by/4.0/. The Creative Commons Public Domain Dedication waiver (http://creativecommons.org/publicdomain/zero/1.0/) applies to the data made available in this article, unless otherwise stated in a credit line to the data. 
gamma (IFN- $\gamma$ ) can promote allograft rejection [7]. In secondary lymphoid organs, $\mathrm{CD} 4^{+} \mathrm{Tms}$ are transformed and amplified into effector $\mathrm{CD} 4^{+} \mathrm{T}$ cells, which aid the production of donor-specific antibodies by $\mathrm{B}$ cells $[8,9]$. With the help of $\mathrm{CD} 4^{+} \mathrm{T}$ cells, the activated alloreactive $\mathrm{CD}^{+} \mathrm{T}$ cells and donor-reactive alloantibodies, together with $\mathrm{CD}_{4}^{+} \mathrm{T}$ cells, cause allograft damage. Thus, basic research is required to better understand the complex immune mechanisms in host sensitization to alloantigens. Subsequently, much needed novel therapeutic approaches to manage sensitized transplant patients should be developed.

In the laboratory, co-stimulatory blockade, such as monoclonal antibodies (mAbs) have been proved to be high efficiency on naïve $\mathrm{T}$ cells in primary organ transplantation [10]. In many mouse transplantation model, Anti-CD154 mAbs combined with anti-lymphocyte function-associated antigen 1 (LFA-1) mAbs can induce tolerance of primary allografts by effectively blocking LFA-1/intercellular adhesion molecule 1 signaling [11-16]. However, in primedsensitized recipients, $\mathrm{mAbs}$ and clinical first-line immunosuppressive agents have limited effects on Tms [17-19].

Thalidomide (TD) was primarily prescribed as a sedative or hypnotic. Afterwards, it was used to treat nausea and to alleviate morning sickness in pregnant women; however, it was quickly withdrawn from the European and Canadian markets in 1961 and 1962 because of its teratogenic effects [20]. However, later, it was found that TD had effects in the treatment of multiple myeloma, erythema nodosum leprosum lesions, and various autoimmune diseases [21]. In recent years, the immunosuppressive and anti-inflammatory effects of TD have been proven in organ transplantation [22-25] and in the treatment of other diseases [26, 27]. Administration of minimal or moderate TD doses can exert immunosuppressive effects to prevent acute cardiac allograft rejection; indeed, its synergism with some clinical medications can significantly improve the survival of heart grafts [24, 25].TD has been described as having a ability on the suppression of tumor necrosis factor-alpha (TNF- $\alpha$ ) and the modulation of interleukins [28]. TD increases the degradation of TNF- $\alpha$ mRNA to control its protein level in monocytes and macrophages [29, 30]. Recent studies have suggested that members of the TNFR-TNF superfamily might be crucial for the generation of Tms and the maintenance of high levels of antigen-reactive $\mathrm{T}$ cells [31]. These results allowed us to hypothesize that TD might ameliorate acute allograft rejection by acting against memory cells.

In the present study, we firstly assessed TD and its synergistic effect combined with co-stimulation blockade using anti-CD154 and anti LFA-1 antibodies in skinprimed heart transplantation. We then studied TD's in vivo mechanism of action, which provided a therapeutic breakthrough in clinical organ transplant research.

\section{Results \\ Allograft survival is significantly prolonged in pre- sensitized recipients treated with $T D+m A b s$}

Our previous research showed that BALB/c hearts would be rejected within 7 days (mean survival time) in naïve wild-type (WT) C57BL/6 recipients; however, rejection was accelerated to within 4 days in mice sensitized using $\mathrm{BALB} / \mathrm{c}$ skin [32]. Thus, we investigated whether the accelerated rejection response could be diminished using TD alone or combined with $\mathrm{mAbs}$ in a skin-primed heart transplant model (HTm). C57BL/6 mice that were pre-sensitized with $B A L B / c$ skin were transplanted with hearts from $B A L B / c$ donors, and the recipients were randomly allocated into four groups (based on the treatment protocol shown in Table 1), with six mice in each group. As displayed in Fig. 1a, in comparison with the control group ( $3.5 \pm 0.5$ days), there was a significant extension in survival time of the cardiac graft after mAbs ( $6 \pm 0.9$ days $)$ and TD $(6 \pm 1.1$ days $)$ treatments $(P<0.05)$. The treatment effect was further enhanced by treatment with $\mathrm{TD}+\mathrm{mAbs}$, which improved the mean survival time (MST) of the grafts to $13.5 \pm 4.9$ days $(P<0.01)$. Thus, TD showed synergistic effects when combined with costimulatory blockade in suppressing secondary cardiac allograft rejection.

Another important consideration is the effect of drug toxicity on the graft recipients. To explore this question, body weight changes after heart transplantation were analyzed. After drug treatment, we found there was a small change in body weight, which could probably be explained as a reaction to the surgical trauma (Fig. 1b). Taken together, these data suggested that the allograft survival time could be significantly extended $(P<0.01)$ without obvious adverse reactions.

\section{TD + mAbs decreased the proportions of Tms and the functions of lymphocytes, but increased Tregs in skin- primed recipients during the secondary heart transplantation}

For alloantigen-primed mice, Tms exist primarily in the spleen and lymph nodes. Homing of effector Tms, especially splenic Tms, is pivotal in the rejection of secondary transplantation [33, 34]. Therefore, the memory phenotype of the recipient splenocytes 4 days after heart transplantation was investigated. In contrast to the skinprimed HTm control group, the treatment groups did not show markedly different proportions of memory $\mathrm{CD} 4^{+} \mathrm{T}$ cells in the spleens of the recipients $(P>0.05$, Fig. 2c). In all treatment groups, there was a significant decrease in the proportion of memory $\mathrm{CD}^{+} \mathrm{T}$ cells among $\mathrm{CD}^{+} \mathrm{T}$ cells, and this decrease was significantly 
Table 1 Experimental treatment groups

\begin{tabular}{lll}
\hline Skin-primed HTm model & Reagent & Treatment \\
\hline Control & Saline & Anti-LFA-1 (0.1 mg) and anti-CD154 (0.25 mg/d) were administered i.p. on days 0, 2, \\
mAbs & anti-LFA-1 and anti-CD154 & $\begin{array}{l}\text { and } 4 \text { after transplantation. TD (100 mg/kg/day) was administered i.g. on days 0-10 } \\
\text { after transplantation, the same as the saline. }\end{array}$ \\
TD & TD & \\
TD + mAbs & TD, anti-LFA-1, and anti-CD154 & \\
\hline
\end{tabular}

$(P<0.01)$ enhanced the TD + mAbs group (Fig. 2a, d). Meanwhile, the $\mathrm{CD} 4^{+} \mathrm{Foxp}^{+}$Tregs proportion among recipient splenocytes increased in all treatment groups, with a significant increase in the combined treatment group $(P<0.001)$ (Fig. $2 b, \mathrm{e})$.

The spleens of the recipient mice were harvested on day 4 after transplantation, and to perform mixed lymphocyte reaction (MLR) assays, splenocytes were prepared to assay the alloreactivity of lymphocytes. As shown Fig. 2f, in contrast to the skin-primed HTm control group, the groups receiving TD or mAbs monotherapy $(P<0.01)$ both showed effective suppression of splenocyte alloresponses. Notably, TD showed a marked synergistic effect in combination with $\mathrm{mAbs}$ to restrain the alloresponses of the splenocytes compared with that of the skin-primed HTm control group $(P<0.001)$.
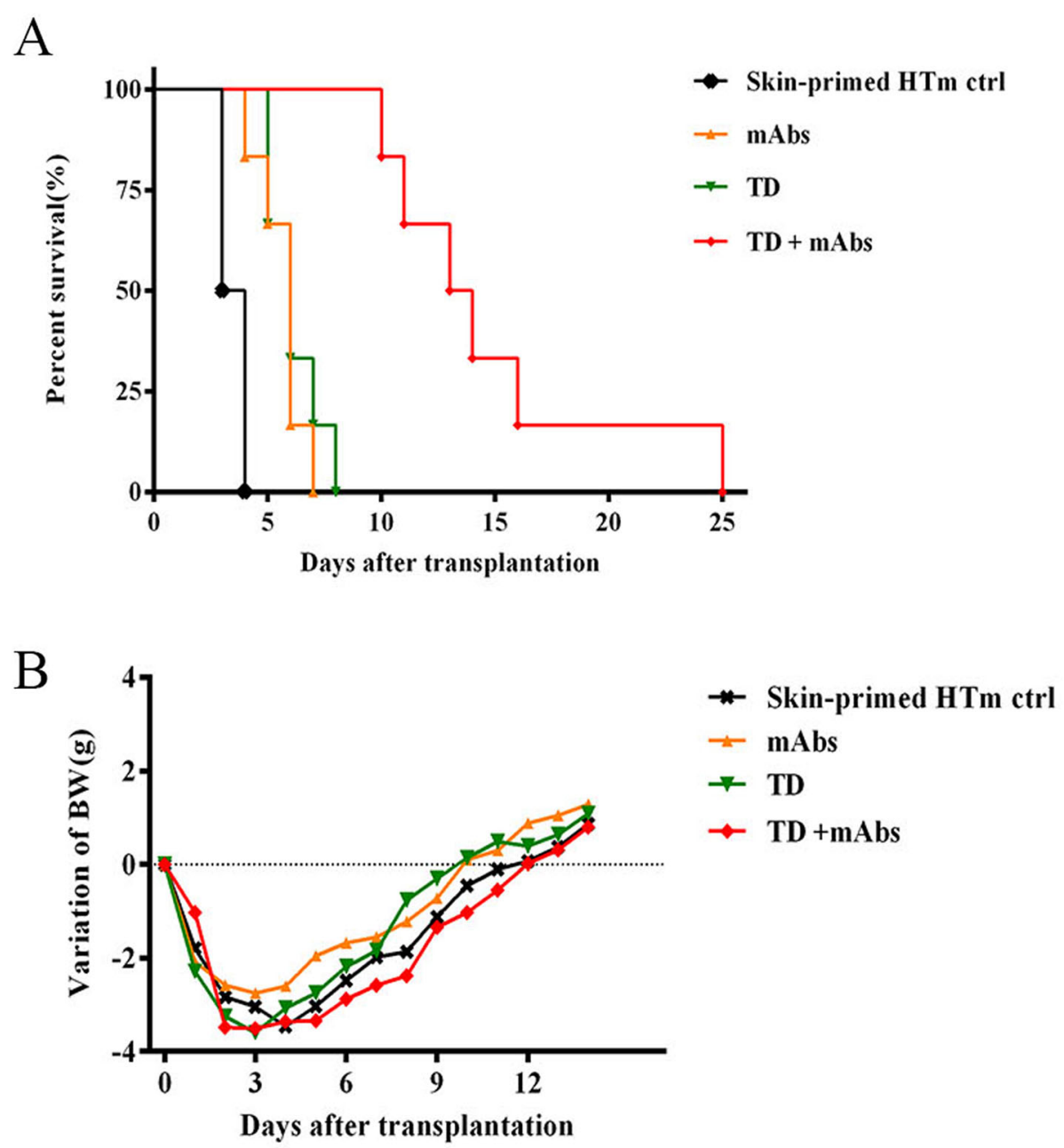

Fig. 1 Survival time of cardiac allografts and changes in body weight in mice receiving allografts after transplantation. Heterotopic vascularized hearts from BALB/C mice were transplanted into skin-primed C57BL/6 recipients. a Graft survival time shown as a Kaplan-Meier curve for the four represented sets (control, TD group, mAbs, and TD + mAbs groups). The MST of these four groups were 3.5 $\pm 0.5,6 \pm 1.1,6 \pm 0.9$, and 13.5 \pm 4.9 days, respectively. $\mathbf{b}$ Body weight change curve of the recipient mice. Trends of the four different sets were similar indicating almost no differences among them 


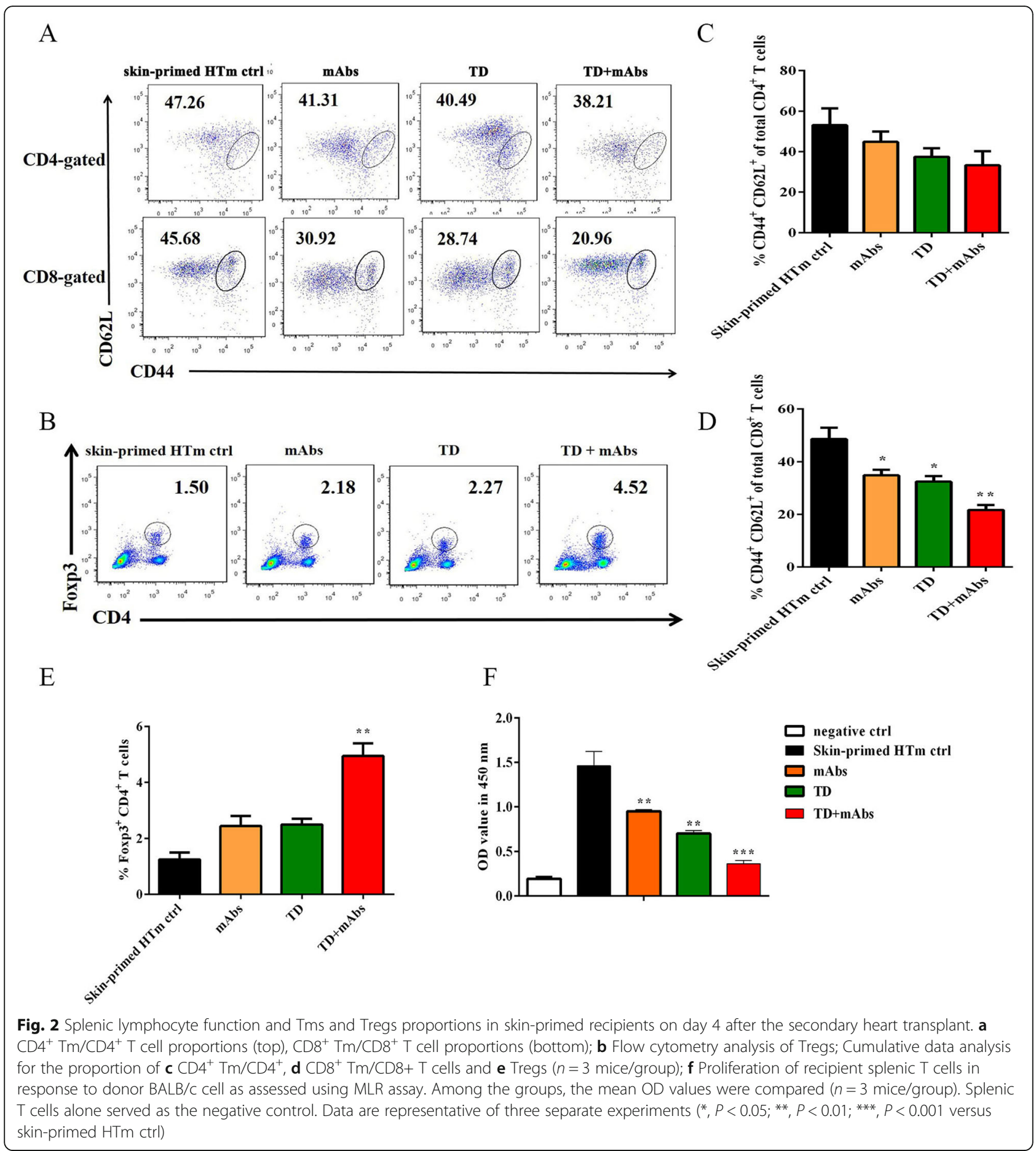

The combined treatment group showed an intact myocardial structure and fewer inflammatory cells infiltrating the graft

Next, we investigated the influence of the combined treatment on day 4 after heart transplantation. Allografts from each group were subjected to histological sectioning and hematoxylin and eosin (H\&E) staining. As shown in Fig. 3a, in the control group, the allografts showed extensive necrosis of myocardial cells, massive infiltration of inflammatory cells, and a large amount of thrombus. Contrastingly, the grafts from the mAbs and TD groups showed moderate inflammatory cell infiltration and tissue damage, and a smaller amount of thrombus. In contrast to the above allografts, in the grafts from TD + mAbs group, the myocardium was very well preserved, with no evidence of degeneration, 


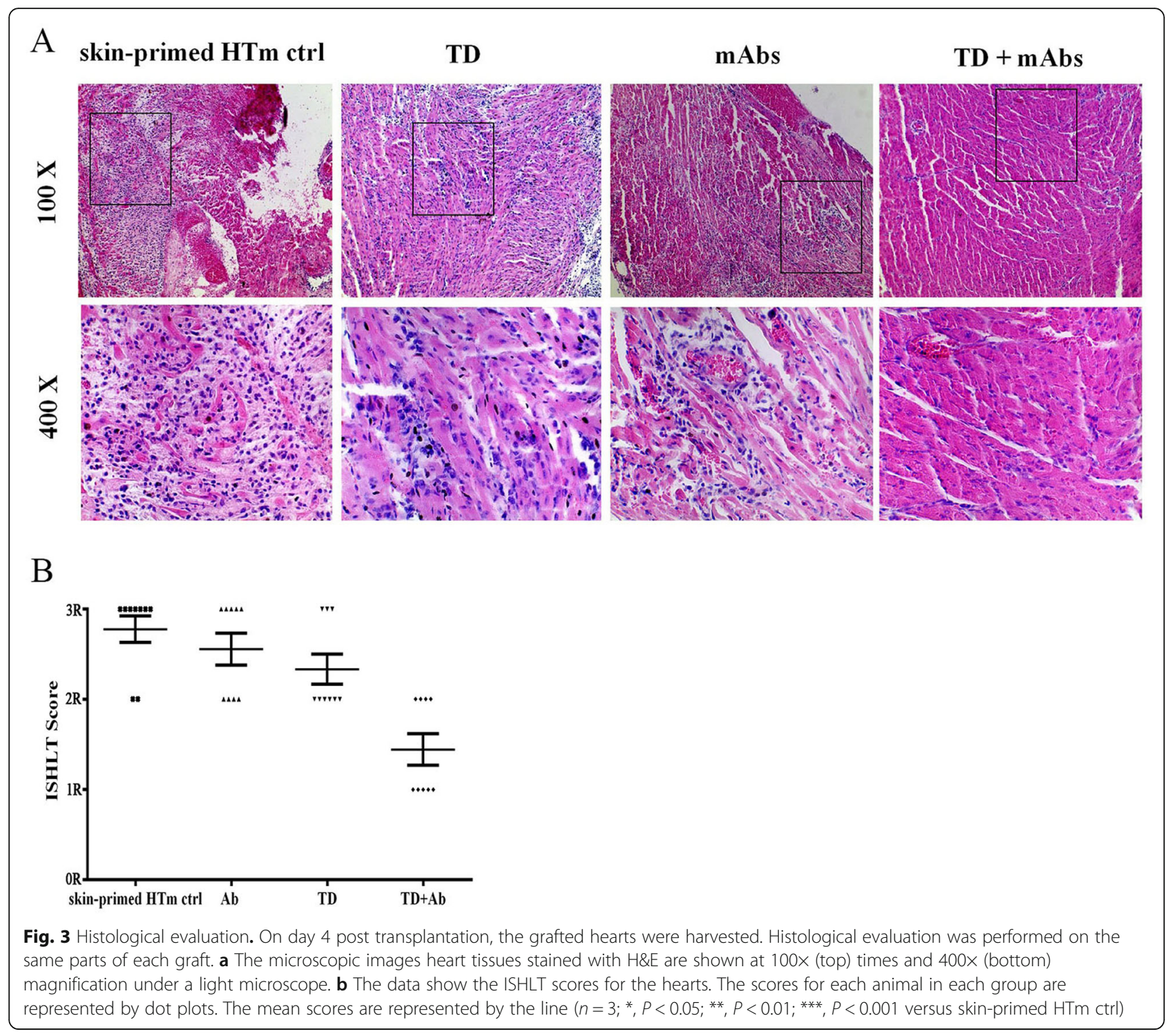

destruction, or inflammatory cells infiltration. The overall scores of rejection/inflammation were measured using the International Society for Heart and Lung Transplantation (ISHLT) ranking (Fig. 3b). The rankings given for the TD + mAbs group were significantly lower than those for the skin-primed HTm control group $(P<0.05$ in each comparison). This result indicated that TD combined with blockade of co-stimulatory molecules provided enhanced protection from rejection Treatment with TD could provide some protection against accelerated rejection; however, when combined with co-stimulatory molecules blockade, this limited protection was promoted significantly.

\section{Production of rejection and tolerance-related cytokines in} the allografts and recipient sera

To investigate the mechanism by which TD provides graft protection, total RNA was extracted from the allograft and quantitative real-time reverse transcription PCR (qRT-PCR) was used to determine the relative expression levels of cytokines. Figure 4a shows reductions in the relative mRNA expression levels of the genes encoding tumor necrosis factor alpha (TNF- $\alpha$ ), interferon gamma (IFN- $\gamma$ ), and interleukin (IL)-4 in all treatment groups. The expression levels of these genes were dramatically lower in the TD + mAbs group compared with those in the skin-primed HTm control group $(P<0.001$, $P<0.01$, and $P<0.01$, respectively). The relative expression levels of IL-2 mRNA were significantly enhanced in the TD and TD + mAbs groups $(P<0.01)$. IL-10 and forkhead box P3 (FOXP3) mRNA relative expression levels were significantly increased in $\mathrm{TD}+\mathrm{mAbs}$ group $(P<0.001)$.

There is a consensus in clinical research that heightened expression levels of the genes encoding the 

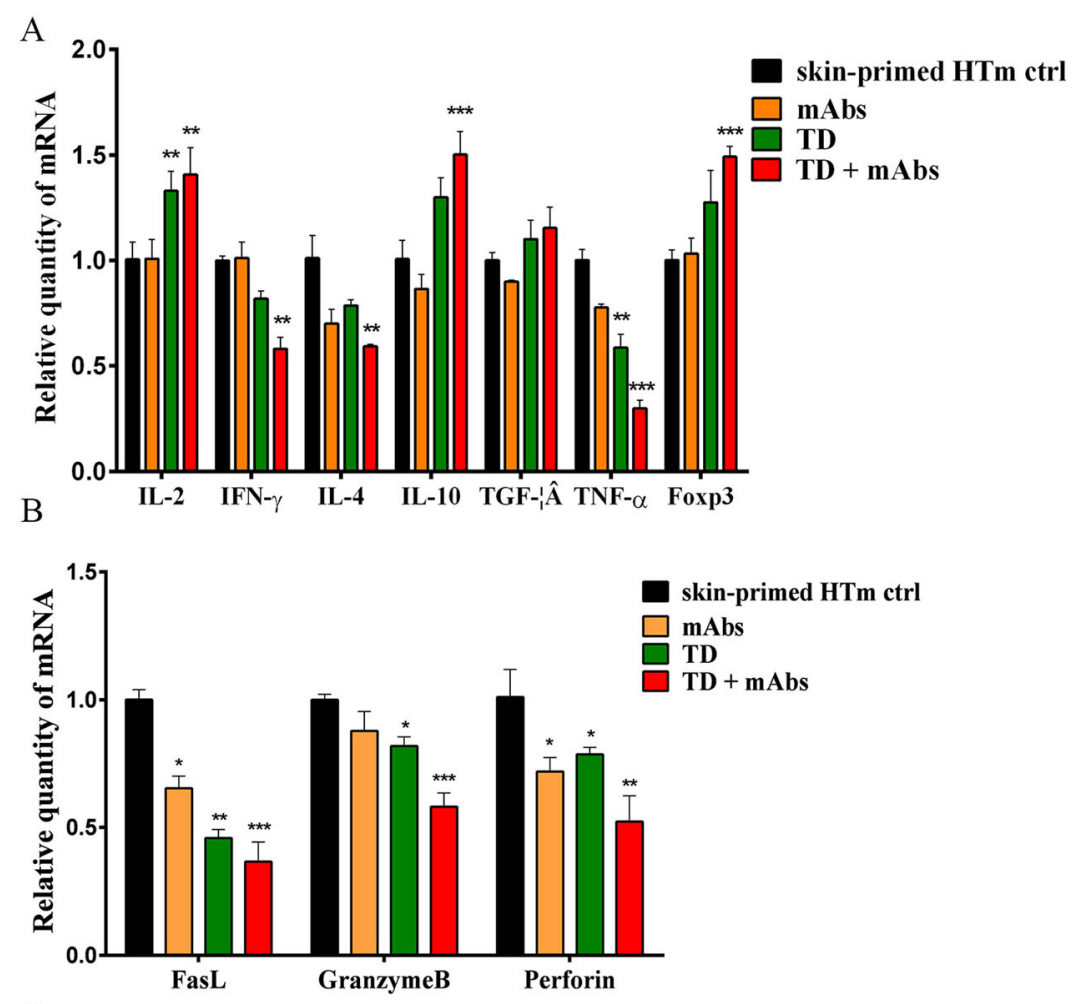

$\mathrm{C}$
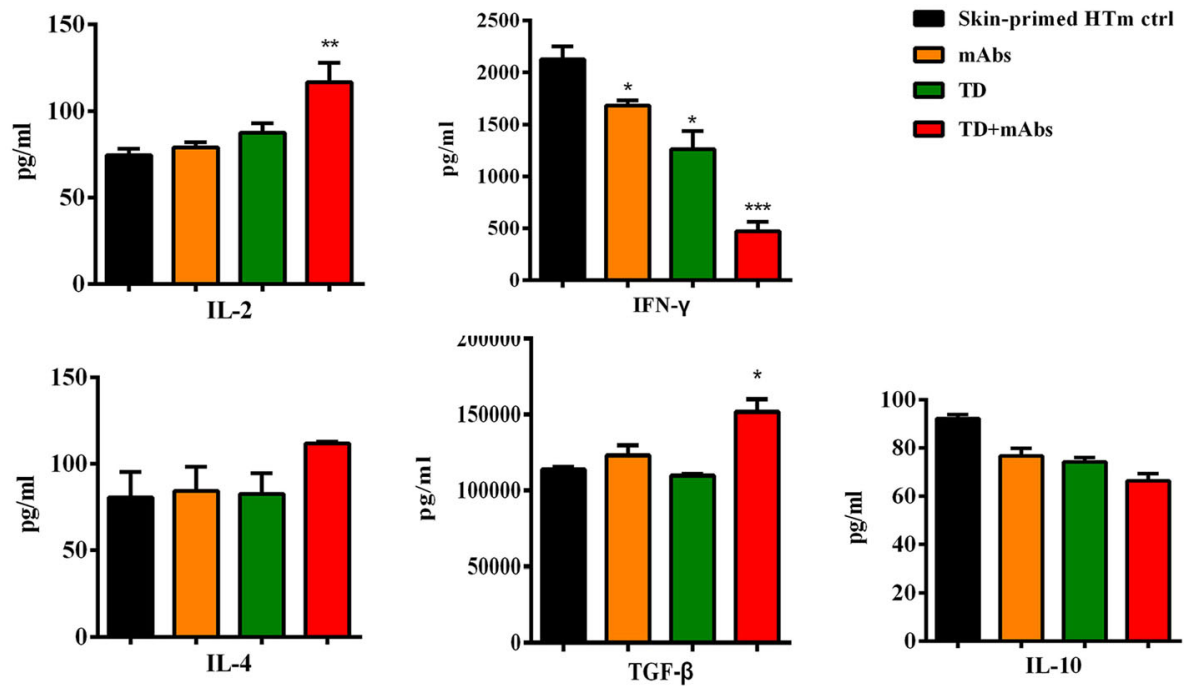

Fig. 4 The expression levels of rejection and tolerance-related cytokine genes in allografts were detected using qRT-PCR and the levels of rejection and tolerance-related cytokines in the sera of the recipients were detected using ELISA. On day 4 post-transplantation, allografts and sera were harvested from the skin-primed recipients. a Expression levels of the genes encoding IL-2, IFN- $\gamma$, IL-4, IL-10, TGF, TNF-a, and Foxp3 within the allografts. $\mathbf{b}$ Expression levels of the genes encoding Fasl, Granzyme B, and Perforin within the allografts. c The protein levels of IL-4, IL2, IFN- $\gamma$, TGF- $\beta$, and IL-10 in the recipient sera. The reactions were repeated three times and the data represent three separate experiments $(n=3$ mice per group; ${ }^{*}, P<0.05 ;{ }^{* *}, P<0.01 ;{ }^{* * *}, P<0.001$ versus skin-primed $\mathrm{HTm}$ ctrl)

cytotoxic molecules perforin and granzyme B within the allograft are characteristic of acute rejection. As shown in Fig. 4b, the relative expression levels of perforin and granzyme B were significantly reduced in the TD + mAbs group compared with skin-primed HTm control group $(P<0.01 ; P<0.001$, respectively). Compared with the TD, mAbs monotherapy group, TD combined with mAbs show a synergistic effect on the relative expression levels of perforin and granzyme B mRNA. We also assessed the levels of the mRNA encoding the effector 
molecule FasL, which induces target cell death via cytotoxic T lymphocytes. Compared with skin-primed HTm control group, the expression of FasL was significantly decreased in all treatment groups.

At 4 days after heart transplantation, the levels of rejection and tolerance-related cytokines (IL-2, IL- 4, IFN$\gamma$, IL-10, and TGF- $\beta$ ) in the recipients' serum were analyzed using an enzyme-linked immunosorbent assay (ELISA) (Fig. 4c). Compared with their levels in the sera of the skin-primed HTm control group, the combined treatment enhanced the level of IL-2 and TGF- $\beta$, and reduced the level of IFN- $\gamma$ significantly $(P<0.01 ; P<0.05$; $P<0.001$, respectively), However, the serum levels of cytokines IL- 4 and IL-10 remained unchanged among the four groups.

\section{TD + mAbs decreased humoral immunity in the skin-} primed HTm

Flow cytometry was used to detect the production of donor-specific antibodies at 4 days after heart transplant in the skin-primed recipients. At this time point, the control recipient mice showed high IgG and IgM levels. As shown in Fig. 5, mAbs has limited effects on the production of donor-specific antibodies, and in combination with TD, they could further enhance the inhibition of antibody production (Fig. 5b, c). TD alone had no effect on IgG2a production; however, when combined mAbs, an obvious reduction in IgG2a levels was observed compared with skin-primed HTm control group.

\section{Discussion}

In the present study, we showed the immunosuppressive effect of TD alone or combined with clinical costimulatory blockade in a clinically relevant pre-sensitized mice cardiac transplantation model. The dosage of TD used was $100 \mathrm{mg} / \mathrm{kg} /$ day, whereas, previous studies generally used TD at $0-10 \mathrm{mg} / \mathrm{kg} /$ day without toxic effects [24, 25]. However, we observed that TD at $200 \mathrm{mg} / \mathrm{kg} /$ day had no toxic effects but further extended the survival time of cardiac allografts in skin-primed HTm, and did not affect the recipients' body weight ( $n=12$ for each group, data not shown). Therefore, TD at $100 \mathrm{mg} / \mathrm{kg} /$ day TD was chosen for the present study. The results showed that treatment with TD combined with mAbs had synergistic immunosuppressive effects to prolong allograft survival compared with that observed in non-or mono-therapy recipients.

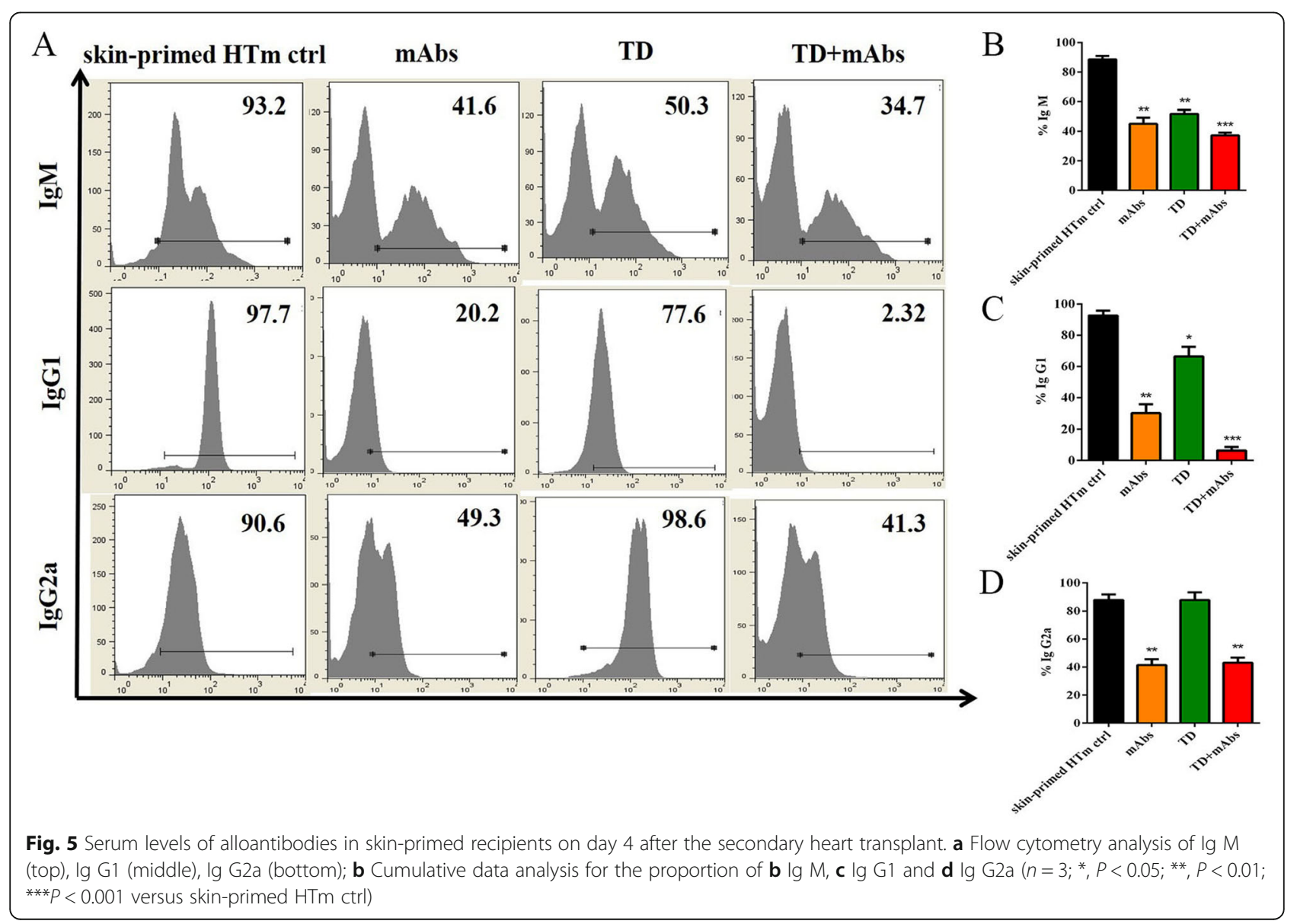


The emergence of memory cells before transplantation causes damage to allografts by mediating transplant rejection and blocking the induction of transplant tolerance $[8,25,35]$. In our study, treatment had no effect on memory $\mathrm{CD}^{+}{ }^{+} \mathrm{T}$ cell, although $\mathrm{TD}+\mathrm{mAbs}$ could significantly decrease the level of IFN- $\gamma$. This phenomenon confirmed that IFN- $\gamma$ makes a critical difference in maximizing the function of $\mathrm{T}$ cells [36]. Thus, TD may weaken the Tms that are derived from effector $\mathrm{T}$ cells, which could be explained by the MLR. This finding contributes to our understanding of the mechanism of graft rejection in mice that lack or block CD154, because memory $\mathrm{CD}_{4}^{+} \mathrm{T}$ cells can mediate allograft rejection [37]. Compared with their naïve counterparts, Tms may have differential requirements for co-stimulation signal pathway blockade, allowing them to easily escape the costimulation blockade, and thus contribute to acute or subacute rejection [17]. In our study, compared with monotherapy treatment, TD combined with mAbs effectively decreased the proportion of $\mathrm{CD}^{+} / \mathrm{CD} 44$ (high)/ $\mathrm{CD} 2 \mathrm{~L}^{+} \mathrm{T}$ cells in recipient spleen. This might be the dominant effect of the combined treatment in resisting rejection. The synergistic effect of monoclonal antibodies and TD might reflect a suppression of memory $\mathrm{T}$ cells by TD and an inhibition of naïve $\mathrm{T}$ cell reaction to the alloantigen by monoclonal antibodies. Here, combined treatment could prolong allograft survival owing to these two treatments affected different $\mathrm{T}$ cell groups in the re-transplantation mouse model. The in-depth mechanism for the interaction of the two treatment or the crossover point of the two pathways should be further identified.

Several mechanisms of combined treatment might involve in protecting allografts in skin-primed HTm models. The Fas-FasL (Fas ligand) system is significantly associated with programmed cell death [38]. FasL is an effector molecule that is involved in cytotoxic T lymphocyte killing of target cells $[39,40]$. Therefore, the FasFasL axis seems to act as an effector for cytotoxic $\mathrm{T}$ lymphocyte-mediated killing of virus-infected or cancer cells, similar to the perforin-granzyme axis [41]. In our study, combined treatment significantly reduces the expression of FasL mRNA, which is the same as perforin and granzyme $\mathrm{B}$, these might be another mechanism for prolonging graft survival, but should be further verification.

Compared with other groups, the heart allograft tissues from skin-primed recipients receiving the combined treatment showed lower levels of inflammatory infiltration and less damage to myocardial structure. The results of qRT-PCR showed that the combined treatment could significantly reduce the levels of the rejectionrelated protein IFN- $\gamma$ within the allograft and in the recipient serum, which implied that the combined treatment inhibited the IFN- $\gamma$-related effector function of infiltration T cells. TD combined with mAbs also synergistically upregulated the expression of FOXP3 in the allograft. These two effects protected the allograft and promoted long-term survival.

Flow cytometry showed that the fraction of $\mathrm{CD}^{+}{ }^{+} \mathrm{FOXP}^{+}{ }^{+}$regulatory $\mathrm{T}$ cells among splenic $\mathrm{T}$ cell increased after the combined treatment. These results indicated that TD combined co-stimulation blockade protected the allograft by promoting the amount of Tregs. The expression of TGF- $\beta$ was upregulated in the serum after combined treatment. We hypothesized that increased population of Tregs induced by TD might be TGF- $\beta$ producing Th3 cells ( $\mathrm{T}$ helper type 3 cells), which overlap with naturally occurring Tregs, have been identified as regulators in oral tolerance [42]. The tolerance induced by IL-10-secreting $\mathrm{T}$ regulatory cells 1 ( $\mathrm{Tr} 1$ cells), which have been proven to suppress antigenspecific immune responses and to downregulate the pathological immune response in vivo [43]. However, the expression levels of IL-10 in recipient sera did not differ among the treatment groups. Above all, TGF- $\beta$ promotes the production of Tregs, which would help to prolong allograft survival.

Several studies have reported that costimulatory blockade alone induces allograft immune tolerance by mediating regulatory $\mathrm{T}$ cell production, but has no effect on Tms-mediated immune rejection [44, 45]. Tms produce effector cytokines in situ to replenish extra immune cells that can mediate early graft tissue damage. IFN- $\gamma$ is generally considered a characteristic proinflammatory molecule that is associated with destructive allograft immunity. In the present study, the ELISA and qRTPCR results indicated that TD, mAbs, and TD + mAbs treatments could significantly reduce the secretion of IFN- $\gamma$. Specifically, IFN- $\gamma$ limits $\mathrm{CD} 4^{+}$regulatory $\mathrm{T}$ cell expansion and decreases CD25 and FOX3 expression $[36,46]$. Tregs are very sensitive to IL-2, and are expanded when conventional T cells produce IL-2 [47], which suggested that combined treatment might induce the robust production of IL-2 by cytotoxic CD 4 Th1 cells, thereby enabling expanded Tregs to express more CD25 and FOXP3.

Memory B cells are likely to be a critical cause of eventual rejection, even when Tms are suppressed. Memory B cells have a preferential growth advantage over naïve $B$ cells when activated and during proliferation, as well as being converted to alloantibody secreting plasma cells during the secondary response, making it possible to prevent the adoption of anti-CD154mediated grafts $[2,48]$. In our study, the mAbs and combined treatment decreased IgM/IgG1/IgG2a alloantibodies production in the recipient mice, which was consistent with the results of a previous study showing 
that treatment with anti-CD154 could decrease the production of alloantibodies [49]. The results suggested that this suppression contributed to prolonging the survival of secondary cardiac allografts.

In our study, combined treatment regimen did not significantly extend the survival period. There are several explanations for this phenomenon. First, the combined treatment could not dramatically affect the proportion of memory $\mathrm{CD} 4^{+} \mathrm{T}$ cells. When the drugs were withdrawn, the Tms cells were activated, proliferated, and converted to effector $\mathrm{T}$ cells, and the subsequent restoration of IFN- $\gamma$ levels would maximize the function of $\mathrm{T}$ cells, which could facilitate B cell secretion of alloantibodies. Secondly, memory B cells are deemed to have priority in interacting with Tms, which can secrete the three cytokines IL-2, IL-4, and IL-10 simultaneously [50]. In the presence of low CD40 levels, compared with naïve B cells, memory B cells show an enhanced ability to differentiate into immunoglobulin secreting cells [48]. Memory B cells can be influenced by the low concentration or by withdrawal of the immunosuppressant, and in the secondary response, cells will be active, proliferative, and converted into alloantibody secreting plasma cells. Thus, continuous administration the regimen could be used as a supplement in a follow-up experiment.

\section{Conclusions}

In summary, the results of the present study demonstrated the potential of TD in the field of organ retransplantation, suggesting that TD could be used as an effective supplement in clinical immunosuppressive application. Impaired memory CD8+ T cells reproduction or effector $\mathrm{T}$ cell function, upregulated levels of TGF- $\beta$ producing Tregs, inhibition of cytotoxic effector cell function, and inhibition of inflammatory cell infiltration into the allograft could be included in the machinery of allograft protection. Clinical experiments to reveal the mechanisms by which TD extends the survival of secondary cardiac allografts are currently in progress. Future studies will also seek to identify the signal pathways that regulate the expression and function of the FasFasL and perforin- granzyme B systems in the cytotoxic effector cells.

\section{Methods}

\section{Animals and drugs}

Female BALB/c (H-2d) and C57BL/6 (B6, H-2b) mice, aged 8-12 weeks old, were bought from the Slac Laboratory Animal Co. Ltd. (Shanghai, China). C57BL/6 were used as graft recipients and BALB/c (H-2d) as donors. A specific pathogen free facility was used to breed and maintain the mice. The mice were sacrifice by inhaling $\mathrm{CO}_{2}$ after experimentation. The experiments were performed in accordance with the guidelines of the Animal
Care and Use Committee and Ethics Committee of Xiamen University (Committee's reference number: XMULAC20170243).

TD (CAS Number: 50-35-1) was purchased from Sigma-Aldrich Chemical Co. USA. Antibodies produced by Bioexpress (West Lebanon) were administered to the mice: anti-CD154 (MR-1), anti-LFA-1 (M17 / 4), and their isotype controls.

\section{Skin-primed murine heart transplantation model (skin- primed $\mathrm{HTm}$ )}

Full-thickness, circular trunk skin tissues with a diameter of $1.2 \mathrm{~cm}$ from $\mathrm{BALB} / \mathrm{c}$ mice were engrafted onto the lumbar region of C57B6 mice. Alloantigen-primed mice were defined as those recipients that rejected the $\mathrm{BALB} / \mathrm{c}$ skin at 4 weeks post-transplantation. Vascularized heterotopic hearts were transplanted into C57B6 recipients from Balb/c donors, using anastomosis to the vessels of the neck with a previously described nonsuture cuff technique $[51,52]$ at 4 weeks post-skin grafting. Graft survival after transplantation was monitored using twice-daily palpation. For 15 consecutive days, body weights were measured daily. The complete loss of a palpable heartbeat in the neck was defined as rejection.

\section{Treatment protocol}

Treatments for the various drugs are summarized in Table 1.

\section{Histological analysis}

Transplanted hearts were harvested on day 4 after transplantation, fixed in $10 \%$ neutral buffered formalin, embedded in paraffin, bisected lengthwise, and cut into 5$\mu \mathrm{m}$ sections for H\&E staining using routine methods. Histological evaluation was done using a score modified from the ISHLT [53]. The grades were defined as follows: $0 \mathrm{R}=$ no rejection; $1 \mathrm{R}$ (mild rejection) $=$ evidence of perivascular infiltrate, interstitial infiltrate, or both with up to 1 focus of myocyte damage; 2R (moderate rejection) $=$ two or more infiltrate foci with related myocyte damage; $3 R$ (severe rejection) = the infiltrate was diffuse and had multifocal myocyte damage \pm edema, \pm hemorrhage, \pm vasculitis. Two pathologists who were blinded to the treatment modalities performed the pathological evaluations.

\section{Mixed lymphocyte reactions (MLR)}

A standard one-way MLR was performed, as described previously [32]. Briefly, nylon wool columns (Wako, Osaka, Japan) were used to isolate splenic cell suspensions from the spleens of C57B6 mice for use as responder cells. Spleen cells from the donors were used as stimulator cells, which were treated with $40 \mathrm{lg} / \mathrm{mL}$ mitomycin (Amresco, Solon, OH, USA) before being 
subjected to the MLR assay. Proliferation assays used stimulator cells $\left(10^{5}\right)$ cultured with responder cells $(5 \times$ $10^{5}$ ) in Roswell Park Memorial Institute (RPMI) 1640 medium with $10 \%$ fetal bovine serum, $1 \%$ penicillin, and $1 \%$ streptomycin in 96-well plates. Negative controls comprised responder cells grown in medium lacking the stimulator cells. The cells were mixed and incubated at $37^{\circ} \mathrm{C}$ for $72 \mathrm{~h}$ in a $95 \%$ humidified air with $5 \%$ carbon dioxide. After $72 \mathrm{~h}$, cell proliferation was measured using the 5'-bromodeoxyuridine (BrdU) method (Roche, Germany). The percent inhibition values were calculated with respect to the negative control and stimulated control values. The measurements were performed in triplicate.

\section{Flow cytometry}

Lymphocytes were isolated from the spleens of the recipient mice on day 4 after transplantation for flow cytometry analysis. Lymphocytes were labeled using the following antibodies, all of which were obtained from Biolegend (San Diego, CA, USA): Fluorescein isothiocyanate (FITC)-conjugated anti-CD4 (GK1.5), FITCconjugated anti-CD8 (53-6.7), Phycoerythrin (PE)-conjugated anti-CD44 (IM7), PECy5-conjugated anti-CD62L (MEL-14), PE-conjugated anti-IgM (RMM-1), FITCconjugated anti-IgG1 (RMG1-1), and FITC-conjugated anti-IgG2a (RMG2a-62). Mouse regulatory $\mathrm{T}$ cells (Tregs) were stained using a kit from eBioscience (San Diego, CA, USA, Ca. No. 88-8111). Negative controls comprised conjugated isotype antibodies. A FACScan flow cytometer (Partec Co., Görlitz, Germany) was used to analyze the stained cells. FLOWJo 7.5.5 software was used to analyze the data.

\section{Quantitative real-time reverse transcription-polymerase chain reaction}

On day 4 post-transplantation, the grafts were excised from the recipients. The Trizol reagent (Invitrogen, Carlsbad, CA, USA) was used to isolate RNA from the heart allografts following the manufacturer's protocol. A ReverTra Ace ${ }^{\circ}$ qPCR RT Kit (code no. FSQ-101) and a $\mathrm{SYBR}^{\circ}$ Green Realtime PCR Master Mix -Plus- (code no. QPK-212, $212 \mathrm{~T}$ ) (Toyobo, Japan) were used to perform reverse transcription and PCR, respectively. The StepOne Real-Time PCR System (Applied Biosystems, Carlsbad, CA, USA) was used to perform the data analysis. The normalizing control gene was Actb (encoding $\beta$-actin), and the reactions were performed three times. Table 2 shows the primers used in the present study.

\section{Enzyme-linked immunosorbent assay}

On day 4 post-transplantation, serum was sampled from the recipient mice. Commercially available kits (Yikesai Bioproduct Limited Company, Qingpu, Shanghai, China)
Table 2 qRT-PCR primers used in the present study

\begin{tabular}{|c|c|c|}
\hline \multicolumn{3}{|c|}{ Sequences of the primers $\left(5^{\prime}-3^{\prime}\right)$} \\
\hline $\begin{array}{l}\text { Target } \\
\text { gene }\end{array}$ & Forward & Reverse \\
\hline$\beta$-actin & $\begin{array}{l}\text { CATCCGTAAAGACCTCTA } \\
\text { TGCCAAC }\end{array}$ & ATGGAGCCACCGATCCACA \\
\hline TNF-a & $\begin{array}{l}\text { CATCTTCTCAAAATTCGA } \\
\text { GTGACAA }\end{array}$ & $\begin{array}{l}\text { TGGGAGTAGACAAGGTAC } \\
\text { AACCC }\end{array}$ \\
\hline $\mathrm{IFN}-\gamma$ & $\begin{array}{l}\text { CGGCACAGTCATTGAAAG } \\
\text { CCTA }\end{array}$ & $\begin{array}{l}\text { GTTGCTGATGGCCT } \\
\text { GATTGTC }\end{array}$ \\
\hline $\mathrm{IL}-2$ & $\begin{array}{l}\text { GGAGCAGCTGTTGATGGA } \\
\text { CCTAC }\end{array}$ & $\begin{array}{l}\text { AATCCAGAACATGC } \\
\text { CGCAGAG }\end{array}$ \\
\hline $\mathrm{IL}-4$ & $\begin{array}{l}\text { TCTCGAATGTACCAGGAG } \\
\text { CCATATC }\end{array}$ & $\begin{array}{l}\text { AGCACCTTGGAAGCCCTA } \\
\text { CAGA }\end{array}$ \\
\hline IL-10 & $\begin{array}{l}\text { GACCAGCTGGACAACATA } \\
\text { CTGCTAA }\end{array}$ & $\begin{array}{l}\text { GATAAGGCTTGGCAACCC } \\
\text { AAGTAA }\end{array}$ \\
\hline FOXP3 & CAGCTCTGCTGGCGAAAGTG & $\begin{array}{l}\text { TCGTCTGAAGGCAGAGTC } \\
\text { AGGA }\end{array}$ \\
\hline TGF- $\beta$ & $\begin{array}{l}\text { TGACGTCACTGGAGTTGT } \\
\text { ACGG }\end{array}$ & $\begin{array}{l}\text { GGTTCATGTCATGG } \\
\text { ATGGTGC }\end{array}$ \\
\hline FasL & GCCCATGAATTACCCATGTCC & $\begin{array}{l}\text { ACAGATTTGTGTTGTGGT } \\
\text { CCTT }\end{array}$ \\
\hline Perforin & $\begin{array}{l}\text { AACTCCCTAATGAG } \\
\text { AGACGCC }\end{array}$ & $\begin{array}{l}\text { CCACACGCCAGTCG } \\
\text { TTATTGA }\end{array}$ \\
\hline $\begin{array}{l}\text { Granzyme } \\
\text { B }\end{array}$ & CCACTCTCGACCCTACATGG & $\begin{array}{l}\text { GGCCCCCAAAGTGACATT } \\
\text { TATT }\end{array}$ \\
\hline
\end{tabular}

were used to detect IL-2, IL-10, IL-4, IFN- $\gamma$, and TGF- $\beta$ using ELISA following the manufacturer's protocol. Each reaction was repeated three times. Known amounts of the purified recombinant murine cytokines were used to construct a standard curve.

\section{Statistical methods}

The Kaplan-Meier method was used to calculate and compare the mean survival times (MSTs) of the four groups. One-way analysis of variance (ANOVA) was used to analyze the data from the flow cytometry, MLR, qRT-PCR, and ELISA experiments, and were expressed as the mean \pm SEM. A Bonferroni correction was calculated and applied for multiple comparisons. $P<0.05$ was taken to indicate statistical significance; $P<0.01$ and $P<$ 0.001 indicate very and extremely significant differences, respectively. GraphPad Prism ${ }^{\circ}$ software (GraphPad, Inc., La Jolla, CA, USA) was used to perform all the analyses.

\section{Abbreviations}

TD: Thalidomide; Abs: Monoclonal antibodies; Tms: Memory T cells; IFNү: Interferon gamma; LFA-1: Anti-lymphocyte function-associated antigen 1; ICAM-1: Intercellular adhesion molecule; HTm: Heart transplantation model; MST: Mean survival time; MLR: Mixed lymphocyte reaction; H\&E: Hematoxylin and eosin; ELISA: Enzyme-linked immunosorbent assay; qRT-PCR: Quantitative real-time reverse transcription PCR; TNF-a: Tumor necrosis factor alpha;

FOXP3: Forkhead box P3 


\section{Acknowledgments}

The authors would like to thank Jingru Huang, Haiping Zheng and Xiang You, the experimentalists at Central Laboratory, School of Medicine, Xiamen University for their technical assistance with flow cytometry.

\section{Authors' contributions}

$Z Q$ and GY conceived the project, designed and supervised the Experiments. $M Z$ and $Y M$ performed the experiment. $K T$, $L Z$ and $Y C$ analyzed the data. JG took care of the animals. ZW and YL drafted the manuscript. All authors reviewed the draft manuscript and approved the final version of the manuscript.

\section{Funding}

This work was supported by the Provincial Natural Science Foundation of Fujian (grants number 2018D0022), the Fujian Provincial Health Education Joint Research Project (WKJ2016-2-20), the National Natural Science Foundation of China (81771721), and the National Key R\&D Program of China (2018YFA0108304). Funders had no role in study and collection of data, analysis, interpretation of data and writing of the manuscript.

\section{Availability of data and materials}

The datasets analysed during the current study are available from the corresponding author on reasonable request.

\section{Ethics approval and consent to participate}

The experiments were performed in accordance with the guidelines of the Animal Care and Use Committee and Ethics Committee of Xiamen University (Committee's reference number: XMULAC20170243).

\section{Consent for publication}

Not applicable.

\section{Competing interests}

Each author approved the final version of this manuscript. They report no conflict of interest.

\section{Author details}

'Xiang'an Branch, The First Affiliated Hospital of Xiamen University, Xiamen 361100, Fujian, China. ${ }^{2}$ The Fifth Hospital of Xiamen, Xiamen 361100, Fujian, China. ${ }^{3}$ Organ Transplantation institute, School of Medicine, Xiamen University, Xiamen 361100, Fujian, China. ${ }^{4}$ Fujian Key Laboratory of Organ and Tissue Regeneration, Xiamen 361100, Fujian, China. ${ }^{5}$ Grade 2015 Clinical Medicine, Fuzhou Medical College of Nanchang University, Fuzhou 344000, Jiangxi, China. ${ }^{6}$ School of Medicine, Guangxi University, Nanning 530004, Guangxi, China.

Received: 16 May 2019 Accepted: 7 April 2020

Published online: 16 April 2020

\section{References}

1. McFarland RD, Douek DC, Koup RA, Picker LJ. Identification of a human recent thymic emigrant phenotype. Proc Natl Acad Sci U S A. 2000;97(8): 4215-20.

2. Sanz I, Wei C, Lee FE, Anolik J. Phenotypic and functional heterogeneity of human memory B cells. Semin Immunol. 2008;20(1):67-82.

3. Tan CD, Sokos GG, Pidwell DJ, Smedira NG, Gonzalez-Stawinski GV, Taylor DO, Starling RC, Rodriguez ER. Correlation of donor-specific antibodies, complement and its regulators with graft dysfunction in cardiac antibodymediated rejection. Am J Transplant Off J Am Soc Transplant Am Soc Transplant Surg. 2009;9(9):2075-84.

4. Dhanda R, Shah Y, Bardapure M, Bhattacharjya S, Sharma AK. Excellent renal allograft survival in donor-specific antibody transplant patients-role of intravenous immunoglobulin and rabbit antithymocyte globulin. Transplantation. 2009:88(3):444

5. Sprent J, Surh CD. T cell memory. Annu Rev Immunol. 2002;20:551-79.

6. Kaech SM, Wherry EJ, Ahmed R. Effector and memory T-cell differentiation: implications for vaccine development. Nat Rev Immunol. 2002;2(4):251-62.

7. Schenk AD, Nozaki T, Rabant M, Valujskikh A, Fairchild RL. Donor-reactive CD8 memory T cells infiltrate cardiac allografts within 24-h posttransplant in naive recipients. Am J Transplant Off J Am Soc Transplant Am Soc Transplant Surg. 2008;8(8):1652-61.
8. Zhang Q, Chen Y, Fairchild RL, Heeger PS, Valujskikh A. Lymphoid sequestration of alloreactive memory CD4 T cells promotes cardiac allograft survival. J Immunol. 2006;176(2):770-7.

9. Chen Y, Heeger PS, Valujskikh A. In vivo helper functions of alloreactive memory CD4+ T cells remain intact despite donor-specific transfusion and anti-CD40 ligand therapy. J Immunol. 2004;172(9):5456-66.

10. Kirk AD, Blair PJ, Tadaki DK, Xu H, Harlan DM. The role of CD154 in organ transplant rejection and acceptance. Philos Trans R Soc Lond Ser B Biol Sci. 2001;356(1409):691-702.

11. Wang Y, Li D, Nurieva R, Yang J, Sen M, Carreno R, Lu S, Mclntyre BW, Molldrem JJ, Legge GB, et al. LFA-1 affinity regulation is necessary for the activation and proliferation of naive T cells. J Biol Chem. 2009;284(19): 12645-53.

12. Li D, Molldrem JJ, Ma Q. LFA-1 regulates CD8+ T cell activation via T cell receptor-mediated and LFA-1-mediated Erk1/2 signal pathways. J Biol Chem. 2009;284(31):21001-10.

13. Nicolls MR, Coulombe M, Beilke J, Gelhaus HC, Gill RG. CD4-dependent generation of dominant transplantation tolerance induced by simultaneous perturbation of CD154 and LFA-1 pathways. J Immunol. 2002;169(9):4831-9.

14. Corbascio M, Mahanty H, Osterholm C, Qi Z, Pearson TC, Larsen CP, Freise $\mathrm{CE}$, Ekberg H. Anti-lymphocyte function-associated antigen-1 monoclonal antibody inhibits CD40 ligand-independent immune responses and prevents chronic vasculopathy in CD40 ligand-deficient mice. Transplantation. 2002;74(1):35-41.

15. Metzler B, Gfeller P, Bigaud M, Li J, Wieczorek G, Heusser C, Lake P, Katopodis A. Combinations of anti-LFA-1, everolimus, anti-CD40 ligand, and allogeneic bone marrow induce central transplantation tolerance through hemopoietic chimerism, including protection from chronic heart allograft rejection. J Immunol. 2004;173(11):7025-36.

16. Nicolls MR, Coulombe M, Yang H, Bolwerk A, Gill RG. Anti-LFA-1 therapy induces long-term islet allograft acceptance in the absence of IFN-gamma or IL-4. J Immunol. 2000;164(7):3627-34.

17. Zhai Y, Meng L, Gao F, Busuttil RW, Kupiec-Weglinski JW. Allograft rejection by primed/memory CD8+ T cells is CD154 blockade resistant: therapeutic implications for sensitized transplant recipients. J Immunol. 2002;169(8): 4667-73.

18. Valujskikh A, Li XC. Frontiers in nephrology: T cell memory as a barrier to transplant tolerance. J Am Soc Nephrol. 2007;18(8):2252-61.

19. Adams AB, Williams MA, Jones TR, Shirasugi N, Durham MM, Kaech SM, Wherry EJ, Onami T, Lanier JG, Kokko KE, et al. Heterologous immunity provides a potent barrier to transplantation tolerance. J Clin Invest. 2003; 111(12):1887-95.

20. Lenz W. A short history of thalidomide embryopathy. Teratology. 1988;38(3): 203-15.

21. Teo S, Resztak KE, Scheffler MA, Kook KA, Zeldis JB, Stirling DI, Thomas SD. Thalidomide in the treatment of leprosy. Microbes Infect. 2002;4(11):1193-202.

22. Tamura F, Vogelsang GB, Reitz BA, Baumgartner WA, Herskowitz A. Combination thalidomide and cyclosporine for cardiac allograft rejection. Comparison with combination methylprednisolone and cyclosporine. Transplantation. 1990;49(1):20-5.

23. Hellmann K, Duke DI, Tucker DF. Prolongation of skin homograft survival by thalidomide. Br Med J. 1965;2(5463):687-9.

24. Ostraat O, Riesbeck K, Qi Z, Eriksson T, Schatz H, Ekberg H. Thalidomide prolonged graft survival in a rat cardiac transplant model but had no inhibitory effect on lymphocyte function in vitro. Transpl Immunol. 1996; 4(2):117-25.

25. Carvalho JB, Petroianu A, Travolo E, de Oliveira BH, Duarte AB, Alberti LR. Effects of immunosuppression induced by thalidomide and cyclosporine in heterotopic heart transplantation in rabbits. Transplant Proc. 2007;39(5): $1640-1$

26. Yildirim ND, Ayer M, Kucukkaya RD, Alpay N, Mete O, Yenerel MN, Yavuz AS, Nalcaci M. Leukocytoclastic vasculitis due to thalidomide in multiple myeloma. Jpn J Clin Oncol. 2007;37(9):704-7.

27. Chen C, Kuehn C, Bretzel RG, Linn T. Anti-inflammatory thalidomide improves islet grafts survival and functions in a xenogenic environment PLoS One. 2009:4(7):e6312.

28. Peuckmann V, Fisch M, Bruera E. Potential novel uses of thalidomide: focus on palliative care. Drugs. 2000;60(2):273-92.

29. Moreira AL, Sampaio EP, Zmuidzinas A, Frindt P, Smith KA, Kaplan G. Thalidomide exerts its inhibitory action on tumor necrosis factor alpha by enhancing mRNA degradation. J Exp Med. 1993;177(6):1675-80. 
30. Sampaio EP, Sarno EN, Galilly R, Cohn ZA, Kaplan G. Thalidomide selectively inhibits tumor necrosis factor alpha production by stimulated human monocytes. J Exp Med. 1991;173(3):699-703.

31. Croft M. Co-stimulatory members of the TNFR family: keys to effective T-cell immunity? Nat Rev Immunol. 2003;3(8):609-20.

32. Dai $H$, Chen J, Shao W, Wang F, Xu S, Peng Y, Lin Y, Xia J, Ekberg H, Wang $X$, et al. Blockade of CD27/CD70 pathway to reduce the generation of memory T cells and markedly prolong the survival of heart allografts in presensitized mice. Transpl Immunol. 2011;24(4):195-202.

33. Surh CD, Sprent J. Homeostasis of naive and memory T cells. Immunity. 2008;29(6):848-62.

34. Yang J, Brook MO, Carvalho-Gaspar M, Zhang J, Ramon HE, Sayegh MH, Wood KJ, Turka LA, Jones ND. Allograft rejection mediated by memory T cells is resistant to regulation. Proc Natl Acad Sci U S A. 2007;104(50):19954-9.

35. Ge W, Jiang J, Liu W, Lian D, Saito A, Garcia B, Li XC, Wang H. Regulatory T cells are critical to tolerance induction in presensitized mouse transplant recipients through targeting memory T cells. Am J Transplant Off J Am Soc Transplant Am Soc Transplant Surg. 2010;10(8):1760-73.

36. St Rose MC, Taylor RA, Bandyopadhyay S, Qui HZ, Hagymasi AT, Vella AT, Adler AJ. CD134/CD137 dual costimulation-elicited IFN-gamma maximizes effector T-cell function but limits Treg expansion. Immunol Cell Biol. 2013; 91(2):173-83.

37. Xu H, Yan J, Huang Y, Chilton PM, Ding C, Schanie CL, Wang L, Ildstad ST. Costimulatory blockade of CD154-CD40 in combination with T-cell lymphodepletion results in prevention of allogeneic sensitization. Blood. 2008;111(6):3266-75.

38. Strasser A, Jost PJ, Nagata $\mathrm{S}$. The many roles of FAS receptor signaling in the immune system. Immunity. 2009;30(2):180-92.

39. Arakaki R, Yamada A, Kudo Y, Hayashi Y, Ishimaru N. Mechanism of activation-induced cell death of T cells and regulation of FasL expression. Crit Rev Immunol. 2014;34(4):301-14.

40. Suda T, Nagata S. Why do defects in the Fas-Fas ligand system cause autoimmunity? J Allergy Clin Immunol. 1997;100(6 Pt 2):S97-101.

41. Aung S, Graham BS. IL-4 diminishes perforin-mediated and increases Fas ligand-mediated cytotoxicity in vivo. J Immunol. 2000;164(7):3487-93.

42. Faria AM, Weiner HL. Oral tolerance. Immunol Rev. 2005;206:232-59.

43. Groux H, O'Garra A, Bigler M, Rouleau M, Antonenko S, de Vries JE, Roncarolo MG. A CD4+ T-cell subset inhibits antigen-specific T-cell responses and prevents colitis. Nature. 1997;389(6652):737-42.

44. Malm H, Pahlman C, Veress B, Corbascio M, Ekberg H. Combined costimulation blockade prevents rejection of allogeneic islets in mice. Scand J Immunol. 2006;64(4):398-403.

45. Oderup C, Malm H, Ekberg H, Qi Z, Veress B, Ivars F, Corbascio M. Costimulation blockade-induced cardiac allograft tolerance: inhibition of $\mathrm{T}$ cell expansion and accumulation of intragraft cD4(+)Foxp3(+) T cells. Transplantation. 2006;82(11):1493-500.

46. Xiao X, Kroemer A, Gao W, Ishii N, Demirci G, Li XC. OX40/OX40L costimulation affects induction of Foxp3+ regulatory $T$ cells in part by expanding memory T cells in vivo. J Immunol. 2008;181(5):3193-201.

47. Long M, Adler AJ. Cutting edge: paracrine, but not autocrine, IL-2 signaling is sustained during early antiviral CD4 T cell response. J Immunol. 2006; 177(7):4257-61.

48. Fecteau JF, Roy A, Neron S. Peripheral blood CD27+ lgG+ B cells rapidly proliferate and differentiate into immunoglobulin-secreting cells after exposure to low CD154 interaction. Immunology. 2009;128(1 Suppl):e353-65.

49. Nathan MJ, Yin D, Eichwald EJ, Bishop DK. The immunobiology of inductive anti-CD40L therapy in transplantation: allograft acceptance is not dependent upon the deletion of graft-reactive T cells. Am J Transplant Off J Am Soc Transplant Am Soc Transplant Surg. 2002;2(4):323-32.

50. McHeyzer-Williams MG. B cells as effectors. Curr Opin Immunol. 2003;15(3): 354-61.

51. Chen $\mathrm{ZH}$. A technique of cervical heterotopic heart transplantation in mice. Transplantation. 1991;52(6):1099-101.

52. Yan G, Xi Y, Xu S, Lin Y, Chen J, Dai H, Xia J, Li C, Li Q, Li Z, et al. Inhibition of accelerated rejection mediated by alloreactive CD4(+) memory $T$ cells and prolonged allograft survival by arsenic trioxide. Immunol Investig. 2013; 42(5):438-54.

53. Stewart S, Winters GL, Fishbein MC, Tazelaar HD, Kobashigawa J, Abrams J, Andersen CB, Angelini A, Berry GJ, Burke MM, et al. Revision of the 1990 working formulation for the standardization of nomenclature in the diagnosis of heart rejection. J Heart Lung Transplant. 2005;24(11):1710-20.

\section{Publisher's Note}

Springer Nature remains neutral with regard to jurisdictional claims in published maps and institutional affiliations.
Ready to submit your research? Choose BMC and benefit from:

- fast, convenient online submission

- thorough peer review by experienced researchers in your field

- rapid publication on acceptance

- support for research data, including large and complex data types

- gold Open Access which fosters wider collaboration and increased citations

- maximum visibility for your research: over $100 \mathrm{M}$ website views per year

At BMC, research is always in progress.

Learn more biomedcentral.com/submissions 